\title{
A Crisis of Judeoconverso Identity and Its Echoes, 1391 to the Present
}

\author{
David Graizbord
}

In the fall of 1674, Luis Aguilar, a traveling merchant of seventeen years of age, was staying at a hostel in a small Castilian village. A local officer of the law entered the hostel and ordered Luis and his traveling companions to recite Christian doctrine and to cross themselves. According to the policeman, Luis did not know how to do this. Furthermore, Luis spoke Spanish with a Portuguese accent, so the policeman surmised that Luis was a New Christian "Judaizer" and arrested him. Shortly thereafter, lay authorities transferred Luis to the custody of the Holy Office in Valladolid. Under interrogation, Luis declared that he was "a Jew by nation," not a New Christian, and that his parents belonged to one of the many small communities of Portuguese expatriates in the French Basque country. It also became clear that Luis had been born in France and had never been baptized. Crucially, there was no evidence that Luis himself had practiced what the Holy Office and the Iberian Churches called "Judaism" while he was in Spain. No one had accused Luis of promoting this "Judaism" or of aiding anybody who wished to practice it secretly in Iberia or anywhere else. This meant that although Luis was liable for deportation or another punishment as an unwanted alien, technically he fell entirely-or almost entirely_outside the jurisdiction of the Holy Office. Yet, instead of releasing him to secular authorities, which would have been a logical step, the inquisitors did something that may seem surprising, and as far as I know, was out the ordinary: in July of 1675 , they ordered that Luis be baptized. ${ }^{1}$

For the past several decades, it has been quite common for scholars to interpret stories like that of Luis Aguilar in relation to the tumultuous development of the Western Sephardic diaspora from the late sixteenth to the end of the seventeenth century. That is the period on which I will focus here. To this day, specialists in early modern history commonly assert that people such as Luis Aguilar were products of a "return to Judaism" among judeoconversos (also known as New Christians) who fled the Iberian domains. Often, modern

1 Archivo Histórico Nacional (Spain), Inquisición de Toledo, Legajo 183, Expediente 4 (16721678), fol. 1r. The defendant in this case was Teresa de Salazar.

(C) DAVID GRAIZBORD, 2019 | DOI:10.1163/9789004392489_002

This is an open access chapter distributed under the terms of the prevailing CC-BY-NC License at the time of publication. 
academics refer to Judaism much as the émigré polemicists "of the [JudeoPortuguese] Nation" did, namely as a "faith" that the expatriates had yearned to practice in freedom beyond the "Lands of Idolatry." To cite but one example, a prominent scholar stated at a conference in Jerusalem in 2015, that she believes that a majority of judeoconversos who settled in Amsterdam had preexisting "Jewish loyalties." 2 Such assertions are accurate in several individual cases. Yet, I think they are globally inaccurate in a double sense: first, judeoconversos who became Judaicized in exile, by and large, did not quite return "to the faith of their ancestors" themselves; that is because most of them had never known or experienced Jewish life at all; thus, prior to becoming Jews they had no realistic notion of, or relationship to, what one might call a lived, normative Jewish culture, a culture that is, by its very nature, historical, public, and collective, as I will explain below.

Second, Judaism was not and is not a "faith." What I mean is that Judaism was not and is not a creedal "religion" in the Christian sense; furthermore, to the best of my knowledge, in the premodern centuries Jews (as distinct from judeoconversos) generally did not call their culture and way of life "Judaism"that, after all, is a Greek pagan term, one that by the early modern centuries Christians had inherited and made part of their intramural cultural lexicon.

The balance of this paper will be devoted to elaborating on these deceptively simple and perhaps provocative points. My aim will be to suggest that we need to carefully calibrate our understanding and our use of key cultural terms such as "Jew," "Jewish," "Judaism," and even "Sephardic," in order to properly depict and explain the early modern "Western Sephardic diaspora." Toward the end of the exposition, I will return briefly to the case of Luis Aguilar and provide an interpretation that I hope will illustrate how what one might call "the usual" conceptual markers of judeoconverso identity, do not quite capture the cultural vagueness of the New Christians who comprised the New Jewish diaspora. More importantly, these terms do not shed light on what is actually the sociological solidity and relative fixity of those self-same subjects.

Let me begin by recalling that the first and arguably most significant mass conversions of Iberian Jews to Christianity from 1391 to 1415 were a culmination of what Jeremy Cohen has called "Anti-Judaism" and William Chester Jordan has simply characterized as a fateful hardening of Christian attitudes toward

2 I am referring to Miriam Bodian, comment at 7:35-7:36 minutes into the presentation, "Theology and Ideology of Conversos," a paper she delivered at the conference on "The Political Dimensions of the Converso Phenomenon in Portugal and Beyond," 26 May 2015, Van Leer Jerusalem Institute, https://www.youtube.com/watch?v=AG32Z8it5TY (accessed 9 May 2017). 
Jews in the Latin West. ${ }^{3}$ According to the theologians who expressed these attitudes, Jews were dangerous to the wellbeing of Christian communities because Jews believed in, observed, and even preached a "law" called "Judaism," or "The Law of Moses." This "erroneous" faith was supposedly, based on a literal understanding of biblical (or Mosaic) Law combined with grotesque and blasphemous rabbinic readings of the "Old Testament." ${ }^{4}$ The bottom line of this highly invidious approach to cultural difference was that Jews were intolerable as believers in and professors of that faith.

Viewed through the dualistic lens of anti-Jewish theology, "Judaism" was therefore like a dark or inverted mirror image of Christianity-in other words, it was a "religion," albeit a false, diabolical one. Therefore, "Judaism" fit neatly into the sphere of experience that Christian thinkers assigned to the innermost recesses of the heart and the mind. Accordingly, being Jewish meant (supposedly) being persuaded that "Judaism" was the "truth," which—again, supposedly-led to the perdition of the blundering believerin the Law of Moses. By the same token, belief in Christian dogma saved the soul of the adherent. It is hardly surprising that inquisitorial discourse on crypto-Judaism replicated this mistaken analogy between Jewish culture and Christianity and attributed the analogy to New Christians. ${ }^{5}$ An Edict of Faith from seventeenth-century

3 Cohen introduced the term "anti-Judaism" to designate a particular form of late medieval conversionist animus in The Friars and the Jews: The Evolution of Medieval Anti-Judaism (Ithaca: Cornell University Press, 1982); Cohen then defended his conception of it in Jeremy Cohen, Living Letters of the Law: Ideas of the Jew in Medieval Christianity (Berkeley and Los Angeles: University of California Press, 1999). For Jordan's contrasting view, which focuses on political and social developments in France, see for instance William Chester Jordan, The French Monarchy and the Jews: From Philip Augustus to the Last Capetians (Philadelphia: University of Pennsylvania Press, 1989); see also Jordan's review of Cohen's Living Letters of the Law in The Jewish Quarterly Review 91, nos. 1-2 (July-October 2000): 217-19, which, however, only hints of Jordan's broader disagreement with Cohen on the supposed Anti-Jewish turn among Christian theologians of the High Middle Ages.

4 Never mind that the Hebrew Bible and the Old Testament are far from identical, and that Jewish tradition does not recognize anything like an "Old Testament" for the simple reason it does not recognize a "new" one. Such were Christian projections of non-Jewish concepts onto Jewish culture.

5 The late Wilfred Cantwell Smith explained that conventional, modern definitions of "religion" adhere to a Western paradigm that emerged under the impact of the Protestant Reformation. Variants of the paradigm assume that human experience is comprehensible in terms of separate religious ("spiritual") and secular ("material" or "worldly") spheres. These variants also emphasize the elements of theology and inner or spiritual persuasion as essential to religion. See Smith, The Meaning and End of Religion (Minneapolis: Fortress Press, 1962; 1991). In American law, for instance, religion occupies a protected private sphere allotted to faith and worship, while the civic sphere is, in theory, religiously neutral, though individuals may act within that sphere inspired by their religious convictions. To the degree that 
Cuenca states: "By this document we [Inquisitors against heretical wickedness and apostasy ...] exhort you and require [to reveal] if any of you knows [...] that any person [...] has said or affirmed [...] any of the heretical ideas against what our Holy Mother, the Roman Catholic Church teaches. [... To wit,] if any of you has seen or heard it said [...] that the Law of Moses is as good as that of our redeemer Jesus Christ." ${ }^{6}$ (Emphasis added)

In a similar vein, formulaic testimony recorded for purposes of a heresy trial in seventeenth-century Portugal imputes to judeoconverso families a tribal propensity to believe in the salvific power of the Law of Moses: "[ In New Christian families] everyone together and each one on his own, believed in and lived by the Law of Moses, and in it they expected to be saved, and they performed the aforementioned ceremonies in order to observe [that Law], one trusting the others because they were relatives and friends, and of the same nation."7

There is an additional aspect to consider in what concerns Ibero-Christian conceptions of Jews, and therefore of judeoconverso markers of identity: as David Nirenberg has observed, the formation of a class of New Christians from 1391 to 1415 initiated a crisis of social, political, and cultural classification in Castile and Aragon. ${ }^{8}$ I would go even further: Christian and Jewish authorities certainly faced the challenge of classifying New Christians and assigning to them a place in a changing society; but in addition to that, judeoconversos themselves, and their "Old Christian" counterparts, had to navigate uncharted cultural territory on their own. The crisis, therefore, was one of identity, not merely of classification. Each adolescent and adult judeoconverso had to decide who and what he or she was. For their part, neither the "Old Christians" nor the surviving Iberian Jews (that is, those who had resisted conversion) quite knew what to make of the New Christians' identity, and therefore found existing, normative socio-cultural borderlines insufficient, at least in practice if not in theory. To put it simply, virtually everyone-especially New Christianshad to grapple in one way or another with the question of who and what was

Jews have become westernized and secularized in modern times, this conventional, Western model, which compartmentalizes religion and tends to separate it conceptually and practically from political, social, and economic life, is at least partly applicable to them-but not to premodern Jews.

6 Appendix, Edict of Faith (Cuenca, 1624), trans. David M. Gitlitz (here cited with my emendations); Gitlitz, Secrecy and Deceit: The Religion of the Crypto-Jews (Philadelphia: Jewish Publication Society, 1996), 625-27.

7 Arquivos Nacionais/Torre do Tombo, Inquisição de Évora, Processo de André Soito, fol. 15, quoted in Maria Benedita Araujo, "Familia e grupo social no criptojudaísmo português (século XVII)," Oceanos 29 (January 1997): 49-66; here 54.

8 David Nirenberg, "Mass Conversion and Genealogical Mentalities: Jews and Christians in Fifteenth-Century Spain," Past and Present 174, no. 1 (2002): 3-41. 
"Christian"; and who and what was "Jewish." Thus, when scholars who are trying to explain phenomena of religious change and cultural transformation in the early modern Western Sephardic communities, write of New Christian ethnicity as a shared feeling of belonging to a group, as a form of shared culture, we are not just talking about New Christians' and New Jews' familial alliances, economic behavior, shared vernaculars, or consciousness of the group's homeland. Rather, in the case of judeoconversos, we are talking about the shared psychological experience of having been made aware, in one way or another, that they and their families descended from Jews, and of having to face that vexing question of definition unlike anyone else in their milieu, save perhaps for Moriscos. I believe that for purposes of historical interpretation, it is crucial to distinguish that consciousness, that experience of distinctiveness, from New Christians' actual or merely imputed desire to "be Jewish," whatever that meant to them and to others.

But to return briefly to the question of the crisis of identity: to my knowledge there was never a total consensus among Iberian rabbis on the question of whether judeoconversos as a group fit the legal category of אנוסים (anousimcoerced ones; namely, subjects who consciously sin under duress); משומדים (meshummadim - תינוקות שנישבו (tinokot she-nishbu — captured infants; in other words, unwitting sinners); or גוים גמורים (goyim gemurim - complete Gentiles). In the first century or so after the conversions, the responsa vary, sometimes dramatically.

To cite but two examples: in the immediate aftermath of the mass conversions, Rabbi Saadia ben Maimon ibn Danan of Muslim Granada maintained, quite plausibly, that judeoconversos הם אחינו בלי ספק ("hem aheynu bli safek"they are our [Jewish] brethren without a doubt). ${ }^{9} \mathrm{~A}$ few decades later, by contrast, Yaakov Berav of Castile (d. 1546) issued a decision signaling that any judeoconversos found in Iberian Christian realms-even those who avoided sexual contact with Old Christians-were non-Jews by definition. ${ }^{10}$

On the Christian side, evidence of the crisis of identity includes the writing of Father Andrés Bernáldez. Below is an excerpt from his chronicle, entitled Historia de los Reyes Católicos Don Fernando y Doña Isabel (1497). ${ }^{11}$

$9 \quad$ Quoted in Benzion Netanyahu, The Marranos of Spain from the Late 14th to the Early 16th Century, According to Contemporary Hebrew Sources, 3rd ed. (Ithaca: Cornell University Press, 1999), 61.

10 Ibid., 70-71.

11 Andrés Bernáldez, Historia de los Reyes Católicos D. Fernando y Da. Isabel, crónica inédita del siglo XV (Granada: D. José María Zamora, 1856), 1: 97-99. 
The heretical Mosaic depravity reigned hidden and lurking in corners for a long time. [...] It had its beginning [...] in the year 1390 [...] which is when the sacking of the judería took place as a result of the preaching of Friar Vincent [Ferrer, ...] who at that time wished to convert all the Jews in Spain, and thus put an end to the entrenched and foul-smelling synagogue. Yet, their mouths were filled with that gloss, the Talmud, that the rabbis made four-hundred years after the birth of our Redeemer. In that gloss there were [sic.] many great lies; therefore they deny the truth and remain ignorant of $i$. Consequently, Friar Vincent was able to convert but very few; so the people, with resentment, put many to the sword in Castile, and killed many. Then many of them came to the churches, to be baptized themselves; and those who were baptized became Christians, and they were called the Conversos. It is from this that the name "converso" had its beginning. [The name is applied to those] converted to the Holy Faith, which they kept very badly; and those among them who came from it [sic.] for the most part were and remained, secret Jews; and they were neither Jews nor Christians, as they were baptized yet were heretics and without law. That is how that heresy was born. It was so elevated in heresy [sic.], that the learned ones were about to preach the Law of Moses, and the common people could not hide their being Jews.

You may be sure that according to what we saw, that at any time this egregiously wild animal is heresy, and that at that time the disgraceful Jew-heretics fled from ecclesiastical doctrine, and thus fled from the customs of the Christians. [Emphasis added]

Elsewhere I have analyzed the above excerpt word for word. ${ }^{12}$ Suffice it for purposes of the present exposition to note that Bernáldez's portrait of judeoconversos is an intellectual morass. The terminology of identity that he thinks is going to help him pin down the New Christians like a spear-terms like "Jews," "Judaism," "Christianity," "conversos," "heretics," etc.—in fact does nothing besides reveal his own bewilderment. Bernáldez's thinking about New Christians was so muddled that he depicts them incongruously as, errant Christians; as Jews; and as neither Christians nor Jews; as culturally mutable; as almost entirely resistant to cultural change-thus culturally immutable; as surreptitiously subversive; and then as conspicuously, openly subversive. To make things worse, Bernáldez cannot distinguish consistently in his text

12 David Graizbord, "Who and What Was a Jew? Some Considerations for the Historical Study of New Christians," Anais de História de Além-Mar 14 (2013): 15-44. 
between three distinct types: an infidel, an apostate, and a heretic. Significantly, this is the same confusion that shaped the very language of the Holy Office as it approached New Christian suspects. ${ }^{13}$ We recall, for instance, the phrase "Judio Judaizante" (Judaizing Jew) which appears in countless inquisitorial accusations and verdicts. As I have noted elsewhere in my work, ${ }^{14}$ this expression is a contradiction by the very basic terms of Christian theology, according to which a Jew is an infidel who would typically not be subject to inquisitorial investigation (unless he or she were suspected of aiding and abetting the commission of heresy), while a "Judaizer" is a heretic, in other words, a Christian subject, not an unbeliever, who deviates from orthodoxy by supposedly thinking and behaving like a Jew. Another verbal formula that reveals inquisitorial confusion regarding the religious identity of New Christian Judaizers is the common condemnation, "hereje apóstata" - heretic-apostate. The latter conveys the incoherent message that a person who is an undisciplined or dissenting believer in a religion is indistinguishable from a person who renounces belief in that religion altogether.

Such conceptual inconsistency and slippage between ostensibly equivalent terms was a primary symptom of the "crisis of classification" and identity. At the heart of that crisis was the fact that the mass conversions erased the hard and fast cultural demarcations that had for long separated Jews and Christians. At the same time, the conversions had the effect of disconnecting within the life of individuals the reality of familial kinship on one hand, from beliefs and rituals that had marked a Jewish social identity on the other hand. Notably, the mass conversions had the additional effect of introducing a disjuncture between interiority and publicity in the construction and enactment of selfidentity — and thus of driving a wedge between individual self and community.

As I intimated earlier, normative Jewish culture assumes that Jewish identity is public, communal, and historical. Not only the revelation at Sinai, but also the covenant and the ideal images of Jewish national redemption, conform to these three conditions; that is: revelation, the forging of the covenant with God, and redemption all take place in the open and not primarily within the individual soul; they occur in time, and they involve the entire Israelite (and hence Judean) community. By the same token, in premodern Jewish culture, personal identity was coextensive with communal belonging. To be a Jew in sociological and psychological fact had nothing to do with proving one's matrilineal descent (notwithstanding tannaitic injunctions on the subject), or with

13 This paragraph reworks another one in ibid., 23.

14 David Graizbord, Souls in Dispute: Converso Identities in Iberia and the Jewish Diaspora, 1580-1700 (Philadelphia: University of Pennsylvania Press, 2004), 117-18. 
confessing belief in certain theological propositions per se. It simply meant being born into, or joining, and living life within a kehillah kedoshah, that is, a normatively-structured and internally autonomous ethnic and political corporation built in order to allow its members to fulfill their halakhic duties, and thus to sanctify the life of a particular people as a collective.

From all this it follows that the clandestine "Judaism" that the Iberian churches and the Holy Office imagined and claimed to find among judeoconversos, was, in a sense, impossible, if by Judaism we mean the lived culture of medieval and early modern Jews. In fact, "Judaism" was merely figural, even chimerical, inasmuch as it did not bear more than a passing resemblance to an openly Judaic way of life. Yes, educated New Christians had access to some rabbinic sources in the Peninsula, as Yosef Yerushalmi and others have amply proven, ${ }^{15}$ but I hazard that a vast majority of judeoconversos did not have such access, and in any case, to read forbidden books is not the same thing as living in a public Jewish community. Thus, even when one can prove the incidence of "Judaizing" among New Christians after the early sixteenth century - and that is often a big "if" because of the problematic nature of the inquisitorial records - that phenomenon is usually better understood not as an attenuated or residual form of Jewish life, but as a dissident offshoot of Iberian Christianity. Indeed, if we may generalize, what crypto-"Judaism" after the first generations of converts to Christianity had passed on was a cluster of ideas and practices based on, parallel, and opposite to Christian ones, that gave its adherents a sense of dignity, even a makeshift spiritual identity, when the stigma of an imputed Jewishness fell heavily upon their shoulders. In that sense at least, I think Claude Stuczynski is right in saying that patterns of judeoconverso dissidence in Iberia were "counter-cultural," and not merely forms of hybridity. ${ }^{16}$ To that, I would add that crypto-Judaism may also be seen as an exercise in counter-historical narration in the terms suggested years ago by Amos Funkenstein; that is, dissident judeoconversos narrated a type of dissent that was so reliant on the dominant Christian story that they sought to overthrow, that their subaltern narratives of rebellion lacked any independent existence. ${ }^{17}$ To be sure, we can speak at length about mutual cultural formation

\footnotetext{
15 See in particular Yosef H. Yerushalmi, "Marranos Returning to Judaism in the Seventeenth Century: Their Jewish Knowledge and Psychological Readiness" [Hebrew], in Proceedings of the Fifth World Congress of Jewish Studies (Jerusalem: Magnes Press, 1969), 2: 201-9.

16 Claude Stuczynski, "Not Hybridity but Counterculture: Portuguese New Christian Judaizers: Confronting Christianity and Islam in Bragança," in Conversos, marrani e nuove comunità ebraiche in età moderna, ed. Myriam Silvera (Florence: Giuntina, 2015), 61-70.

17 Amos Funkenstein, "History, Counter-History and Memory," in Perceptions of Jewish History (Berkeley and Los Angeles: University of California Press, 1993), 22-49, esp. 36-40.
} 
between Jews and Christians in the pre-modern centuries, but I think that for obvious reasons open Jewish life in Western Christendom, a life that had deep roots in the Orient, was never merely derivative of Christianity, and therefore was neither exclusively countercultural nor counterhistorical. Simply put, premodern European Jews were not dissenting Christians.

From all this it follows, again, that the Jewish culture that exiled judeoconversos absorbed in established Jewish communities of the West such as Venice and Salonika was not the inquisitorial travesty of Jewish culture. The New Jews of the West did not adopt "Judaism." Instead, what they ultimately internalized - some refugees more quickly than others depending on whether they settled among the "Old" Sephardim or among fellow New Christians-was the comprehensive civilization of the nation called Israel. Unlike Christianity, that civilization did not distinguish, at least not sharply, between religiousspiritual and secular spheres of experience.

These observations may seem too obvious to even discuss-or too much like semantic hairsplitting. Yet, unfortunately, our problem is that scholarly literature on the judeoconverso phenomenon does not always do justice to premodern Jewish civilization, and therefore, has some difficulty in interpreting the behavior of New Christians both inside and outside the Iberian Peninsula. To wit: modern scholars have tended to treat Jewish culture as a "faith," and Jews as a "faith-community."

It is only fair to provide a few examples of this tendency. ${ }^{18}$ In 1895 , Joaquim Mendes dos Remédios wrote that Jews and therefore judeoconversos were distinguishable solely by their "religion" — what he called their "beliefs." As late as 1992, Julio Valdeón Baruque, an important medievalist from the Universidad Complutense de Madrid, echoed that general understanding. Valdeón wrote that the conflict between Jews and Christians in Iberia before the general expulsions of 1492-1498 was a struggle "between members of two religious creeds." ${ }^{19}$ This statement begs the question: What was the Jewish "creed"? Was it perhaps Maimonides's list of thirteen principles of faith? Medieval and early modern Sephardic authorities would probably disagree; after all, it was they who kept those selfsame thirteen principles out of the standard Sephardic liturgy. Meanwhile, Valdeón's colleague, the French scholar Joseph Pérez, wrote in a book published in 2007 that medieval Iberian Jews were different from their Muslim neighbors merely "from the religious point of view; but in every

18 I first provided these examples in Graizbord, "Who and What Was a Jew?".

19 Julio Valdeón Baruque, "Motivaciones socioeconómicas de las fricciones entre viejocristianos, judíos y conversos," in Judíos, Sefarditas, Conversos: La Expulsión de 1492 y sus consecuencias, ed. Angel Alcalá, (Valladolid: Ámbito, 1995), 70. 
other way," Pérez argues, they adopted the dominant Arab and Muslim cultural models (emphasis added). ${ }^{20}$ So, for example, according to Pérez, Maimonides was simply an Arab who happened to profess the Mosaic faith. ${ }^{21}$ In other words, he was a kind of early Reform Jew, as it were.

The problem of liberal presentism to which I am pointing is not limited to Hispanists. It extends even to scholars of judeoconversos and of Jewish culture more generally. I recall, for instance, the surprising assertion that one prominent scholar made in 1987 in an attempt to explain the pietistic literature of the Judeo-Portuguese Nation in Amsterdam: "La salvación del alma," he wrote, "es la preocupación máxima del judaísmo" (The salvation of the soul is the highest preoccupation of Judaism). ${ }^{22}$ This assertion is a symptom of a classic, yet nonetheless, false analogy between Jewish culture and Christianity. More accurately, the statement reveals a conflation of the way of life of Jews who lived in autonomous kehillot (communities), with their unique system of law and their socio-political and religious institutions on one hand, and the decorous, austere, contrite and conformist sort of moralism, tinged with a Christian-like emphasis on spirituality, that lay leaders of the Amsterdam Judeo-Portuguese and Judeo-Spanish community espoused during the heyday of the merchant Nação in the 16oos on the other. As Yosef Kaplan's analysis suggests, this latter religion and social ethos, called bom judesmo, helped expatriate judeoconversos negotiate the transition to a full-fledged, Jewish national life. ${ }^{23}$ Yet bom judesmo was itself understandably makeshift and instrumental in nature. ${ }^{24}$

20 Joseph Pérez, History of a Tragedy: The Expulsion of the Jews from Spain, trans. Lisa Hochroth (Urbana: University of Illinois Press, 2007), 11-12.

21 Ibid.

22 He continues, "Un alma que es juzgada cada año en los dias terribles que transcurren entre Rosh Hashana y Yom Kippur. Recordemos también el juicio final.” Henry Méchoulan, Hispanidad y Judaísmo en Tiempos de Espinoza: Estudio y edición anotada de La certeza del camino de Abraham Pereyra, Amsterdam 1666 (Salamanca: Ediciones Universidad de Salamanca, 1987), 62 .

23 Yosef Kaplan, "Bom Judesmo: The Western Sephardic Diaspora," in Cultures of the Jews, ed. David Biale, 3 vols. (New York: Schocken, 2002), 2: 337-67.

24 Scholars of Jews and Jewish civilization find Bom Judesmo interesting, I think, partly because it was one expression of the remarkable creativity and sheer discipline that propelled the merchant Nação throughout the seventeenth century. And this fascination holds true, despite the fact that "The Men of the Nation" were not all New Christians in the first place, let alone New Jews or Jewishly-oriented New Christians. If Daviken StudnickiGizbert is right, close to half of the twenty thousand or so people "of The Nation" in the mid-16oos were not of Jewish ancestry at all. Studnicki-Gizbert, A Nation Upon the Ocean Sea: Portugal's Atlantic Diaspora and the Crisis of the Spanish Empire (Oxford: Oxford University Press, 2007), 10. 
There are, I think, at least two reasons that account for the false analogy to which I have referred. The first is that judeoconversos at large, and in particular newly Judaicized apologists (Isaac Cardoso, Daniel Levi de Barrios, Isaac Orobio de Castro, and others), as well as New Jewish pietists such as the parnass Abraham Pereira - all of whom usually wrote in Western languages-made frequent recourse to the Christian vocabulary of "religion," "faith," and "the soul," to describe the culture of the Jews. Notably, these cosmopolitan authors sometimes portrayed that culture in doctrinal or quasi-doctrinal terms. In the process, they injected key Ibero-Catholic concerns, ideas, and rhetorical styles into the intellectual and devotional life of the "Judeo-Portuguese and Spanish Nation."

It is all well and good to acknowledge a phenomenon of cultural interpenetration between Iberian Christianity and diasporic Judaism in the life of the Nação. Yet the question I wish to pose here is how scholarship might properly understand the complex dynamics of that interpenetration in the lives and identities of New Jews. I think that an incisive portrait of the Judaicization of New Christians in exile, at the very least, demands that historians and literary scholars of cultural transformation in the Western Sephardic diaspora refrain from internalizing the Christian conceptual categories and terminology that judeoconversos took for granted as they entered the Jewish communal fray in Amsterdam, Venice, and similar hubs of the Judeo-Portuguese Nação. Else, scholarship runs the risk of merely parroting the self-justifications that New Jewish writers provided to explain their recently acquired Jewish ardor as something ancient and innate.

The second reason that I believe accounts for the misconception that early modern New Jews in the West comprised a faith-community in the Christian sense is the modern, enlightened viewpoint that has underwritten many historical studies since the nineteenth century. According to a liberal version of that approach, Jews must be defended from racism, and are thus to be understood as a merely "religious" or "confessional" minority, not as a people apart. Jews' ancestral culture therefore need not stand as a "tribal" or "racial" obstacle to their dignity and enjoyment of civic and political rights within the nonJewish nation-state. ${ }^{25}$ It would be a mistake to rest on the victory laurels of

25 As I observe in "Who and What Was a Jew?": "Proponents of the Enlightenment from the eighteenth century onward did not inquire how Jews regarded themselves, and for the most part had no intention of condoning their traditional way of life, which these enlightened men viewed as backward and obscurantist; rather, they prescribed that Jews compartmentalize, privatize, and spiritualize their all-encompassing culture into a 'religion' as a (pre)condition for enjoying political equality. The price of toleration, then, was the Jews' traditional group identity" (25). 
this liberal outlook if, for no other reason that, in some ways, it replicates the artificial separation of Jewish ethnicity and Jews' religious ideology, practice, and social membership that resulted from the mass conversions of 1391, and hence, distorts our perception of medieval and early modern Jewish culture as the New Jews encountered and absorbed it.

Scholarly interest in and misreadings of the Nação have been buoyed over the past few decades by a third factor. I am speaking of scholars' interest in the fluidity and contingency of self-definition. The liminal quality of judeoconverso identities has recently allowed for a scholarship in which essentialism and reductionism give way to more flexible and nuanced conceptions of the self in relation to the social universe. The upshot is a current fascination with the possibility that New Christians and New Jews could thoroughly compartmentalize and spiritualize religion, keep it at arm's length, and then, when it may be useful, activate and deactivate it as if with an electrical switch, according to circumstance.$^{26}$ Some might call this a kind of (proto-) "modern" feature of New Christian and New Jewish identities.

One problem with this last conception is that it does not fully account for the relatively high levels of Jewish acculturation - genuine and deep acculturation into a fundamentally traditional way of life-that members of the Nação eventually achieved in the Atlantic strongholds of bom judesmo, and particularly, in older, more established diasporic centers by the eighteenth century. From that deep acculturation, scholars as wise as Yosef Yerushalmi and Daniel Swetschinski have concluded that New Christian émigrés must have held deep Jewish commitments prior to leaving the Iberian Peninsula. ${ }^{27}$ Thus, the scholars have tended to validate Israël Révah's famous opinion that these persecuted subjects had always been latent Jews. ${ }^{28}$

As someone whose work has focused attention on "New Jews" who were marginal or who dissented from the behavioral ideals of bom judesmo, I am conscious that ideological solidarity and discipline among members of the Nação were sometimes more apparent than real. At the same time, I am aware that such solidarity did exist in general, and that it drew in even ambivalent types who were not sure of who and what they were, in terms of their ideological loyalties. Yet I hazard that the coalescence of communities of New Jews "of the nation" in exile has less to do with any desire to practice a supposed

26 I count myself among the proponents of this kind of interpretation. In fact, the observation that cultural commuters "of The Nation" turned religion on and off as if by an electric switch is mine. Graizbord, Souls in Dispute, 102.

27 Yerushalmi; Daniel M. Swetschinski, Reluctant Cosmopolitans: The Portuguese Jews of Seventeenth Century Amsterdam (London: Littman Library of Jewish Civilization, 2000).

28 Israël Salvator Révah, "Les Marranes," Revue des études juives 118 (1959-1960): 29-77, here 55. 
religion called "Judaism" per se, or with the inculcation of normative Judaic ritual and belief, than with the dynamics of ethnic and political belonging with which New Christians were already familiar from their experience within Iberian contexts.

It is important to underscore that New Christians in Spain and Portugal were reared in a cultural environment in which many if not all Old Christians regarded them viscerally as "Jews" rather than as true co-religionists. Over time, through the practices of endogamy and homogamy, as well as through the concomitant forging of commercial relationships, this sense of social estrangement and genealogical difference coalesced as one of the imaginary bases of the transoceanic Nação, complete with its own merchant houses, religious institutions, patrões (or bosses), an elite of political representatives, sophisticated systems of monetary and non-monetary collection and payment, ${ }^{29}$ and certain mores and unique patterns of sociability firmly anchored in those systems, as well as in such distinctive practices as the use of the Portuguese and Castilian languages. Again, an affinity toward the non-Jewish construct of "Judaism" does not seem to me to have been a cause of that coalescence.

John Hutchinson and Anthony Smith identify an "ethnic group" as a network of people who exhibit six main features: first, common, proper names; second, narratives that explain the common ancestry of the group and proffer a perception of kinship for the group's members, indeed a sense of forming part of a "super-family" (we may view persecution by the Inquisition, and the bloodbased, discriminatory system of genealogical probanza, as stimulants of this perception in the case of New Christians); third, shared historical memories; fourth, elements of a common culture, usually but not necessarily including such aspects as language and customs, ideas about the transcendent, rituals, and so on; fifth, a link with a homeland, articulated as a symbolic attachment when the ethnic group does not actually occupy that place; and sixth, a sense of solidarity on the part of at least some sections of the ethnic population. ${ }^{30} \mathrm{To}$ this definition, I would add that the endurance of these six aspects of ethnicity does not mean that they are static and unchanging, much less "primordial," but rather, that successive generations of people who are somehow socialized into the group receive a knowledge of these aspects, internalize them, and reinvent them according to various circumstances. The bottom line here is that by the

29 See Mauricio Dimant's contribution to this volume. On the dynamics of commercial relationships forged by members of the Nação, see also Studnicki-Gizbert; and Francesca Trivellato, The Familiarity of Strangers: The Sephardic Diaspora, Livorno, and CrossCultural Trade in the Early Modern Period (New Haven: Yale University Press, 2012).

$3^{0}$ John Hutchinson and Anthony D. Smith, eds., "Introduction," in Ethnicity (Oxford: Oxford University Press, 1996), 6-7. 
standards of Hutchinson and Smith's anthropological definition, the Nação was indeed an ethnos, albeit a religiously diverse one.

What, then, should scholars make of the newly acquired Jewish "religion" of the Hebrews of the Portuguese and Spanish Nation? To paraphrase Yosef Kaplan's question in his contribution to this volume, why davka did the New Jews of the Western Sephardic diaspora wish to become Jewish? I cannot answer the question fully, yet it may be helpful to approach facets of the problem in stages.

At this point, it might be apposite to note that early modern Jews seldom, if ever, called their way of life "Judaism" in any language. To the best of my knowledge, they did not have a favorite designation for that culture in any event. Here and there, historians encounter sweeping rabbinic phrases in the documentary sources, such as "The Life of Torah (חיי התורה), "accepting the yoke of heavenly authority" (קבלת עול מלכות השמיים), and "fear of God" ('יראת ה), but I really cannot say that these phrases even come close to what one might call a "standard" designation for an entire culture. It is as though the practical, public, and communal emphases of the culture obviated the need to name it, not to mention the need to define it as a truth-claiming ideology or an "-ism."

Is this to say that the normative Jewish way of life that conversos absorbed outside of the Ibero-Catholic realms cannot be called a "religion"? I have already touched on this question, but it is worthwhile to return to it now. Iberian rabbis before and after the expulsion(s) did, on occasion, use words like dateynu (דתיינו, translatable as "our law" or "our decree") to describe the Jews' ideally comprehensive way of life. In an as-yet unpublished article, I have gone so far as to argue that this use of the word dat during the late Middle Ages was a sign that the rabbis were inching closer to defining their own civilization in the spiritualized terms provided to them by their persecutors, especially by Christian polemicists from the mendicant orders. All the same, I doubt that such linguistic usages erased the sociological and historical anchors of Jewish collectivity. Those anchors existed well before the era of Enlightenment and political emancipation, and have eroded only since then. Those structural bases seem to me to have been ethnic and political in character. In other words, they mirrored - and were thus capable of assimilating — the preexisting sociological underpinnings of the Nação.

To the degree that some New Christians became Judaicized in the "Lands of Liberty," then, they were actually adopting a communal way of life founded on a sense of kinship that they already shared. The principal difference between the diasporic and the Iberian contexts, one might say, was "superstructural," not structural. Specifically, the move to an open or semi-open Jewish life was for New Christian refugees chiefly a matter of adopting and elaborating 
what to the members of the Nação were relatively new narrative justifications and poetic representations of that preexisting sense of ethnic uniqueness. New Christian identities had already been informed by the need to grapple with the genealogical origins and imputed Jewishness of the judeoconverso ethnos.

What I am proposing is that the move from Christianity to open, normative Judaism, did not entail the creation of a religious community per se, or for that matter, the forging of totally disparate individuals into a new ethnic cohort. Rather, it entailed the creative continuation of a kin-group "under new management" (so to speak). Several of the subjects I have studied who settled in France, among other refugees of the Nação, admitted as much in candid-sounding statements. When pressed, they said that they had turned into professing Jews not because they had become persuaded of some great, transcendent truth, but because people in their adopted diasporic communities all spoke Portuguese or Spanish, like them, and were of Iberian origin, like them, and because behaving in accordance with Mosaic Law was "what they [meaning, the resident Iberian expatriates] did over there." One informant, for instance, declared the following: "I don't know for certain what cause [my neighbors in Saint-Esprit, near Bayonne] may have had for catechizing me and persuading me to keep the Law of Moses [...] but I suspect it may have been the fact that over there [that] Law is observed publicly among the Portuguese, and [the fact] that they all know each other and are Portuguese."31

New Christians who became New Jews preserved their own sense of ethnic distinctiveness, I suspect, partly because it fit rather well with the established Jewish model of collective identity as both public, collective, and most of all, ethnic or kin-based.

But, speaking of ethnicity, were the New Jews-or did they become"Sephardim" in the diaspora? The matter is complex. Yes, the Nação originated in Iberian countries that diasporic Jews knew as Sepharad by the 1600 . It is also true that the main diasporic communities of the Nation adopted at least key aspects of minhag Sepharad (custom of Sepharad). Yet, as Ross Brann and Jonathan Ray have shown, the label "Sephardi" was a diasporic, not an Iberian construct. ${ }^{32}$ It was certainly not an adjective or a noun that Jews in the Peninsula had generally used to describe themselves before 1492. There

31 Archivo Histórico Nacional, Inquisición de Toledo, Legajo 177, Expediente 1 (1664-70), fol. $16 \mathrm{v}$.

32 See for example Ross Brann, Power in the Portrayal: Representations of Muslims and Jews in Eleventh- and Twelfth-Century Islamic Spain (Princeton, NJ: Princeton University Press, 2002); Jonathan Ray, After Expulsion: 1492 and the Making of Sephardic Jewry (New York: New York University Press, 2013). 
was something retrospective and idealizing about the "Sephardi" label. This is evidenced by the fact that a few isolated individuals such as Maimonides and Avraham Ibn-Ezra adopted the signifier "ha-Sephardi" only after they had fled the Andalusian-Muslim polity for greener pastures and felt the need to draw up and assert some sort of cultural pedigree.

Miriam Bodian has made the argument that over the centuries New Christians in Iberia lost their connection to the world of the Iberian megorashim and their descendants who took on the Sephardic label. Leaders of the Judeo-Portuguese diaspora abroad tried to rebuild that connection, but ultimately what remained for the New Jews as a social glue, Bodian maintains, is the memory of the converso past, not the Jewish past as such. ${ }^{33}$ If we follow Bodian, then, we must conclude that the New Jews were not really Sephardim far beyond the liturgical sense.

Where would this leave our understanding of "cultural transformation" in the early modern Western Sephardic diaspora? Specifically, if the Jewish culture that the émigré conversos internalized was not a "faith" that "saved" the individual soul; and if it took the New Jews one or more generations to become fully Sephardicized, if at all (especially in the North Atlantic, far away from the Eastern Sephardic diaspora), then what are we cultural historians to make of the Western Sephardic diaspora of the seventeenth century, that economic and cultural apogee of the Men of the Nation? We can turn for part of the answer-an oblique answer - to the anecdote with which I began, namely the strange case of young Luis Aguilar. People like him are significant to the task of rewriting the history of the Western "Sephardic" diaspora precisely because he was not a typical protagonist of that history as its leaders and as modern historians have told it. Luis was not a merchant magnate; he was not a conquistador; he was not a poet or political essayist; he was not a physician, or a pietist, or an intellectual defender of the "excellencies of the Hebrews." He was no martyr, no defender of a nascent ideology of "freedom of conscience," declaiming at an auto-da-fe that the Law of Moses was the true one and that he was ready to die for that faith. Luis was an ordinary bloke. But so were the majority of his fellow nationals. He was far more typical of the Nação than, say, the cultural luminaries Isaac and Avraham Cardoso. And to make matters difficult for him, Luis Aguilar came from a culturally arch-liminal community of Iberian exiles. At that time, his home country, France, unlike the Netherlands, was both a "land of idolatry" and "a land of freedom": there was anti-Portuguese

33 Miriam Bodian, "Hebrews of the Portuguese Nation: The Ambiguous Boundaries of SelfDefinition," Jewish Social Studies 15, no. 1 (2008): 66-80. 
and anti-Jewish sentiment at the local level; "Judaism" was officially illegal. Yet, the regional nobility and the French crown welcomed Portuguese merchants as an economic asset and did not get too involved in the internal life and self-definition of the immigrant population. Some of the members of that population were avid Judaizers; others were not. Many of them oscillated between cultures. In a very real sense, the community of Nouveaux Chrétiens as a whole was neither here nor there, and was both here and there.

As I mentioned at the outset, Luis Aguilar was arrested because a policeman thought that he was a Judaizer. Yet all we really know about Luis is that he called himself a "Jew by nation." Any active ideological or spiritual allegiances and opinions he may have had are actually obscure. The inquisitors who interrogated Luis correctly perceived that he was a kind of cultural blank slate-someone from a "bad" nation of errants, yes, but not especially villainous himself; neither articulate nor inscrutable; neither egregiously offensive nor totally inoffensive. This indeterminacy the Holy Office evidently could not tolerate. For the inquisitors, identity must be integral, clear, and it must always be a matter of declaiming one's subservience to some grand truth-or, alternately, some grand lie. Thus, they took the unusual step of manufacturing Luis Aguilar's social self by having him baptized. But what is lost in that story, and in many of our studies - if we rely too comfortably upon the rhetoric of "Jews" and "Judaism" that predominated in the early modern centuries, and especially if we take the socio-religiously insecure New Jewish leaders and luminaries of the Nação at their word-is that Luis Aguilar, like Bento (not "Baruch," not "Benedictus") de Spinoza, was indeed something and somebody in the streets of his native diasporic Jewish community: Luis and his parents formed part of a commercial and political corporation of long-standing. Despite its actual diversity, that imagined community, the New Christian Nação, already counted with a firm ethnic identity in the terms outlined by Hutchinson and Smith. Old Christians and many Jews associated the New Christian corporation to which Luis belonged with the Jewish people. This was the key circumstance to which the men and women of the Nation were forced to adapt throughout their existence. For better or worse, like the Nação, the Jewish diasporic collective rested on the foundations of ethnicity and relative political autonomy. Whenever social and political winds allowed the men of the nation to explore, to appropriate, and to transvalue that real or supposed Jewish "inheritance," some of them did just that. Yet there was nothing preordained about that outcome. Elective affinities are not indicative of natural preferences. Like Luis Aguilar, the men and women of the Nation were potential Jews and potential Christians simultaneously. 


\section{Bibliography}

Araujo, Maria Benedita. "Familia e grupo social no criptojudaísmo português (século XVII)." Oceanos 29 (January 1997): 49-66.

Archivo Histórico Nacional (Spain), Inquisición de Toledo, Legajo 183, Expediente 4 (1672-1678).

Archivo Histórico Nacional, Inquisición de Toledo, Legajo 177, Expediente 1 (1664-70), fol. $16 \mathrm{v}$.

Bernáldez, Andrés. Historia de los Reyes Católicos D. Fernando y Da. Isabel, crónica inédita del siglo XV. Vol. 1. Granada: D. José María Zamora, 1856.

Bodian, Miriam. "Hebrews of the Portuguese Nation: The Ambiguous Boundaries of Self-Definition." Jewish Social Studies 15, no. 1 (2008): 66-80.

Bodian, Miriam. "Theology and Ideology of Conversos." In “The Political Dimensions of the Converso Phenomenon in Portugal and Beyond," 26 May 2015, Van Leer Jerusalem Institute, at: https://www.youtube.com/watch?v=AG32z8it5TY.

Brann, Ross. Power in the Portrayal: Representations of Muslims and Jews in Eleventhand Twelfth-Century Islamic Spain. Princeton, NJ: Princeton University Press, 2002.

Cohen, Jeremy. Living Letters of the Law: Ideas of the Jew in Medieval Christianity. Berkeley and Los Angeles: University of California Press, 1999.

Cohen, Jeremy. The Friars and the Jews: The Evolution of Medieval Anti-Judaism. Ithaca: Cornell University Press, 1982.

Funkenstein, Amos. Perceptions of Jewish History. Berkeley and Los Angeles: University of California Press, 1993.

Gitlitz, David M. Secrecy and Deceit: The Religion of the Crypto-Jews. Philadelphia: Jewish Publication Society, 1996.

Graizbord, David L. Souls in Dispute: Converso Identities in Iberia and the Jewish Diaspora, 1580-1700. Philadelphia: University of Pennsylvania Press, 2004.

Graizbord, David L. "Who and What Was a Jew? Some Considerations for the Historical Study of New Christians." Anais de História de Além-Mar 14 (2013): 15-44.

Hutchinson, John, and Anthony D. Smith. Ethnicity. Oxford: Oxford University Press, 1996.

Jordan, William Chester. The French Monarchy and the Jews: From Philip Augustus to the Last Capetians. Philadelphia: University of Pennsylvania Press, 1989.

Jordan, William Chester. Review of Jeremy Cohen, Living Letters of the Law. The Jewish Quarterly Review 91, nos. 1-2 (July-October 2000): 217-19.

Kaplan, Yosef. “Bom Judesmo: The Western Sephardic Diaspora." In Cultures of the Jews. 3 vols. Edited by David Biale, 2: 337-67. New York: Schocken, 2002.

Méchoulan, Henry. Hispanidad y Judaísmo en Tiempos de Espinoza: Estudio y edición anotada de La certeza del camino de Abraham Pereyra, Amsterdam 1666. Salamanca: Ediciones Universidad de Salamanca, 1987. 
Netanyahu, Benzion. The Marranos of Spain from the Late 14th to the Early 16th Century, According to Contemporary Hebrew Sources. 3rd ed. Ithaca: Cornell University Press, 1999.

Nirenberg, David. "Mass Conversion and Genealogical Mentalities: Jews and Christians in Fifteenth-Century Spain." Past and Present 174, no. 1 (2002): 3-41.

Pérez, Joseph. History of a Tragedy: The Expulsion of the Jews from Spain. Translated by Lisa Hochroth. Urbana: University of Illinois Press, 2007.

Ray, Jonathan. After Expulsion: 1492 and the Making of Sephardic Jewry. New York: New York University Press, 2013.

Révah, Israël Salvator. "Les Marranes." Revue des etudes juives 118 (1959-1960): 29-77.

Smith, Wilfred Cantwell. The Meaning and End of Religion. Minneapolis: Fortress Press, 1962; repr. 1991.

Stuczynski, Claude. "Not Hybridity but Counterculture: Portuguese New Christian Judaizers: Confronting Christianity and Islam in Bragança." In Conversos, marranie nuove comunità ebraiche in età moderna. Edited by Myriam Silvera, 61-70. Florence: Giuntina, 2015.

Studnicki-Gizbert, Daviken. A Nation Upon the Ocean Sea: Portugal's Atlantic Diaspora and the Crisis of the Spanish Empire. Oxford: Oxford University Press, 2007.

Swetschinski, Daniel M. Reluctant Cosmopolitans: The Portuguese Jews of Seventeenth Century Amsterdam. London: Littman Library of Jewish Civilization, 2000.

Trivellato, Francesca. The Familiarity of Strangers: The Sephardic Diaspora, Livorno, and Cross-Cultural Trade in the Early Modern Period. New Haven: Yale University Press, 2012.

Valdeón Baruque, Julio. "Motivaciones socioeconómicas de las fricciones entre viejocristianos, judíos y conversos." In Judíos, Sefarditas, Conversos: La Expulsión de 1492 y sus consecuencias. Edited by Angel Alcalá. Valladolid: Ámbito, 1995.

Yerushalmi, Yosef H. "Marranos Returning to Judaism in the Seventeenth Century: Their Jewish Knowledge and Psychological Readiness." [Hebrew] In Proceedings of the Fifth World Congress of Jewish Studies. Jerusalem: Magnes Press, 1969. 